International Journal of Advanced Academic Research (Sciences, Technology and Engineering) | ISSN: 2488-9849

Journal DOI: 10.46654/ij.24889849

Vol. 7, Issue 1 (January, 2021)|www.ijaar.org

\title{
PRODUCTION OF BIOETHANOL FROM RICE AND MILLET HUSKS
}

\author{
${ }^{1}$ A.Z. Gwandu, ${ }^{2}$ A.A. Farouq, ${ }^{2}$ A.S. Baki and ${ }^{1}$ D.N. Peni \\ ${ }^{1}$ Department of Science Laboratory Technology, Waziri Umaru Federal Polytechnic Birnin \\ Kebbi \\ ${ }^{2}$ Department of Microbiology, Usmanu Danfodiyo University Sokoto, Sokoto State \\ E-mail: zarauatikugwandu@gmail.com
}

\begin{abstract}
This study was based on the production of bioethanol as an alternative source of fuel using rice and millet husks. Proximate, elemental and thermogravimetric analysis (TGA) were conducted of the biomass. The proximate analysis revealed that millet husk had the highest moisture content of $26.67 \pm 0.58 \%$ when compared with rice husk $8.17 \pm 0.29 \%$. The TGA of rice husk had a high endset temperature of $355.51^{\circ} \mathrm{C}$ and a weight loss of $-48.23 \%$, millet husk had low endset temperature of $349.21^{\circ} \mathrm{C}$ and a weight loss of $-44.25 \%$. When thirty grams (30g) of the substrates was used, rice husk revealed the highest reducing sugar content of $2.59 \pm 1.24 \mathrm{~mol} / \mathrm{dm}^{3}$ when compared to millet husk that had $1.63 \pm 0.68 \mathrm{~mol} / \mathrm{dm}^{3}$. Rice husk indicated low yield after 7 days of fermentation period but showed a significantly high yield in the volume of ethanol produced $68.67 \pm 17.69 \mathrm{~g} / \mathrm{l}$ and millet husk had a yield of $79.80 \pm 0.93 \mathrm{~g} / \mathrm{l}$. This indicated that both rice and millet husks were potent for bioethanol production with millet husk having the highest yield.
\end{abstract}

KEY WORDS: Aspergillus niger, Bioethanol, Enzymatic, Hydrolysis Millet Husk, Production and Rice Husk 


\section{INTRODUCTION}

High cost fossil fuel prices and national security concerns have sparked interest in bio-fuels in continental Africa (Pillay and Da Silva, 2009). Currently, the problems of energy and environment are large obstacles to the development of human civilization. Energy security (bio or fossil origin) like food security in Africa is a crucial element in sustaining development and technology progress in Africa (Leuenberger and Wohlgemuth, 2006).

Bioethanol is considered as an important renewable fuel to partly replace fossil-derived fuels. The world production of bioethanol increased from 50 million $\mathrm{m}^{3}$ in 2007 to over 100 million $\mathrm{m}^{3}$ in 2012. Brazil and the United States represent approximately $80 \%$ of the world supply, mostly using corn or sugarcane (Kang et al., 2014). For waste plant materials to be valuable, they must be converted to fuel as a sustainable substitute to fossil fuel. Therefore, there is a need for renewable energy resources from non-edible agricultural sources such as millet husks to replace fossil forms. This is because gas emissions from plant feedstock fuel are less than those emitted by fossil forms and thus beneficial to the environment and global warming (Demirbas, 2005; Hongguang, 2006). Therefore, more attention has been given to the development of biofuels from agricultural residues

Northern Nigeria is commercially known to be producers of energy crops whose residues can be used in promoting the production of second generation biofuels. These lignocellulose wastes accumulate in large quantities and can cause environmental problems. Since the chemical composition of these materials consists mainly of polymer sugars (cellulose and hemicellulose) and lignin, these chemical components can be recycled and used for the production of a number of value-added products such as ethanol, food additives, organic acids, enzymes, and others. This trigger this research work to

I determine the proximate and elemental composition of rice and millet husks before pretreatment in production of bioethanol.

Ii determine the thermal properties of the rice and millet husks.

Iii pre treat and hydrolyze the rice and millet husks simultaneously using Aspergillus niger.

\section{METHODOLOGY}

\section{Collection of samples for analysis (Rice and Millet Husks)}

The rice husk was collected using clean nylon leather from 'Kara' market located in Birnin Kebbi metropolis, Kebbi State while millet husk was obtained from Dange-Shuni LGA of Sokoto State. The samples were transported to Agric Laboratory of Usmanu Danfodio University Sokoto for further analysis as described by Rabah et al. (2011). 


\section{Processing of sample for analysis}

The samples collected were air dried for a period of two days and grounded to powdered form using a warring blender and sieve with a mesh size of $0.5 \mathrm{~mm}$. The ground sample was stored after removal of unwanted particles and debris. It was later stored under ambient temperature for further analysis in accordance with the work of Oyeleke and Jibrin (2009).

\section{Proximate Analysis of Samples (Rice and Millet Husks)}

\section{Determination of Moisture Content}

The empty can was weighed $\left(\mathrm{W}_{\mathrm{O}}\right)$, two gram $(2 \mathrm{~g})$ of each sample was weighed and added into the empty can and the weight was taken $\left(\mathrm{W}_{1}\right)$. This was dried in the hot air oven at $105^{\circ} \mathrm{c}$ for $24 \mathrm{hrs}$. It was cooled in a desiccator. The weight of the dry sample was taken as $\left(\mathrm{W}_{2}\right)($ Garba et al., 1996).

$\%$ Moisture $=\frac{\mathrm{W}_{1}-\frac{\mathrm{W}_{2}}{\mathrm{~W}_{1}-\mathrm{W}_{0}}}{\mathrm{~W}_{0}} \times 100$

\section{Determination of Volatile Solids}

The organic matter (volatile solid) was determined by subtracting the percentages of moisture and ash content from 100\% (Garba, 1999).

\section{Determination of Total Solids}

The total solid was obtained by subtracting dry weight $\left(\mathrm{W}_{2}\right)$ from the wet weight $\left(\mathrm{W}_{1}\right)(\mathrm{Garba}$ 1999) using the formula below:

\section{Total Solid = Wet Weight $\left(\mathrm{W}_{1}\right)-$ Dry Weight $\left(\mathrm{W}_{2}\right)$}

\section{Determination of Ash Content}

The crucible was weighed $\left(\mathrm{W}_{0}\right)$ and $2 \mathrm{~g}$ of the sample was also weighed and added to the crucible $\left(\mathrm{W}_{1}\right)$. It was then arranged in the muffle furnace at $600^{\circ} \mathrm{c}$ for $3 \mathrm{hrs}$. The sample was cooled in a desiccator. The crucible and dry ash sample were weighed $\left(\mathrm{W}_{2}\right)$ (Bakare, 1985; Tell, 1984) as shown in the formula below:

$$
\% \text { Ash }=\underline{\mathrm{W}}_{2}-\underline{\mathrm{W}}_{0} \times 100
$$

\section{Elemental Analysis of Rice and Millet Husks Samples \\ Determination of Nitrogen Content}

From the sample, $0.5 \mathrm{~g}$ was weighed and poured into the macro-kjeldahl flask. Mercury catalyst was added and $10 \mathrm{ml}$ of concentrated $\mathrm{H}_{2} \mathrm{SO}_{4}$ acid was added using an automatic pipette. The flask was heated cautiously at low temperature on the digestion stand. This was allowed until the biomass dissolved and a change in color from dark to yellow color was observed. It was allowed to cool down for $24 \mathrm{hrs}$. This was mixed with $50 \mathrm{ml}$ of distilled water. In a conical flask, $20 \mathrm{ml}$ of $\mathrm{H}_{3} \mathrm{BO}_{3}$ indicator was added and attached to the distillation machine. Also, $10 \mathrm{ml}$ of each sample 
was added into macro kjeldahl flask, $40 \mathrm{ml}$ of distilled water plus $20 \mathrm{ml}$ of $10 \mathrm{M} \mathrm{NaOH}$ were added. It was attached to the distillation apparatus to allow the condenser drop water inside and the distillate collected in the conical flask. The device was turned off and the flask was put down and also the conical flask. Titration was done using $0.01 \mathrm{H}_{2} \mathrm{SO}_{4}$ and the process was carried out in triplicate (American Society of Agronomy, 1982). The $\% \mathrm{~N}$ content was obtained using the formula below:

$\% \mathrm{~N}=\underline{\mathrm{T} \times \mathrm{M} \times 0.014 \times \mathrm{DF}} \times 100$

Weight of sample $\mathrm{x}$ Volume

Where: $\mathrm{T}=$ Titre value $\mathrm{M}=$ Molarity of $\mathrm{H}_{2} \mathrm{SO}_{4}, \mathrm{DF}=$ Dilution factor $(50 \mathrm{ml}), \mathrm{Vol}=$ Volume of sample collected for distillation $0.014=$ Constant

\section{Determination of Percentage Carbon}

The percentage carbon (Allen et al., 1974) was estimated using the equation:

$\% \mathrm{C}=0.58 \times$ V.S (Organic matter)

Where: $0.58=$ Conversion Factor for Carbon V.S = Volatile Solids

\section{Determination of Phosphorus Content}

From the ash of the sample obtained, $5 \mathrm{ml}$ of $20 \% \mathrm{HCl}$ was added to dissolve the ash residue and $50 \mathrm{ml}$ volume of distilled water was added and transferred into sample bottles labeled A and B in triplicates each. From the sample bottle, $2 \mathrm{ml}$ was taken and transferred into $50 \mathrm{ml}$ volumetric flask each and $2 \mathrm{ml}$ of phosphorus extraction solution with $2 \mathrm{ml}$ of ammonium molybdate solution were added. Distilled water was added to three quarter of the volumetric flask to reach the mark and $1 \mathrm{ml}$ of dilute stannous chloride was added. An apparent change in color to blue color was observed. It was shaken and poured into a cubet and inserted into a spectrophotometer at $660 \mathrm{Nm}$ wavelength (Bakare, 1985). The \% phosphorus content was obtained using the formula:

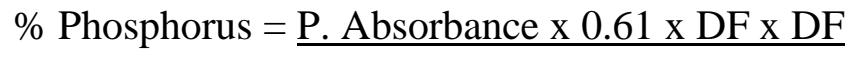

Atomic weight of Phosphorus, Where DF $=$ Dilution factor $(50 / 2), 0.61=$ Constant and Atomic weight of $\mathrm{P}=30.97$

\section{Determination of Potassium Content}

The source of light, compressor and gas were turned on. On the device, potassium was set to be identified and the ignition was also switched on. The machine was allowed to warm for some minutes. In distilled water, the reading was 0 while at $10 \mathrm{ppm}$ working solution, 100 plus reading was obtained and the device was adjusted to 100 . It was repeated till the machine calibrates itself. For the sample, $0.5 \mathrm{ml}$ was diluted with $20 \mathrm{ml}$ of distilled water and the reading was taken for samples A and B (Bakare, 1985). A graph of transmittance against concentration was plotted and below formula was used to determine potassium (K) content; 
$\mathrm{K}=\mathrm{N} \times \mathrm{DF} \times \mathrm{DF}$, Where: $\mathrm{K}=$ Potassium content, $\mathrm{N}=$ value of $\mathrm{K}$ obtained from the flame photometer, $\mathrm{DF}=$ Dilution factor

\section{Determination of Carbon to Nitrogen ratio(C: $N)$}

The carbon to nitrogen ratio was determined by calculating the ratio of organic carbon content to that of nitrogen content (Bagudo et al., 2008):

$$
\mathrm{C}: \mathrm{N}=\frac{\% \text { Organic carbon in the sample }}{\% \text { Nitrogen in the sample }}
$$

\section{Determination of Thermal Stability of Rice and Millet Husks}

The DTG machine was switched on and a spatula was used to set the pans. After some few minutes, the device was let open and sample was collected with the aid of a spatula on a pan, the pan was placed back in the device and closed. Temperature was set to $400^{\circ} \mathrm{C}$ for $15 \mathrm{~min}$. On a system screen, parameters including temperature program, sampling parameters (where the sample name, sample weight in mg and molecular weight) were set. Start button on the screen was clicked to begin the analysis. The device continued to measure the temperature per unit time. The temperature was increased to $450^{\circ} \mathrm{C}$ for the sample to reach its thermal stability. It was then allowed to cool down before opening the machine during which the TGA result was obtained (Abdullahi, 2012).

\section{Isolation, Characterization and Identification of Aspergillus niger}

A. niger was isolated from soil samples collected from different areas of Biological Science Garden using a clean hand trowel and sterile nylon and transported to Mycology laboratory of UDU, Sokoto for microbiological analysis following standard procedures described by Cheesbrough (2003) and Oyeleke and Manga (2008).

\section{Preparation of Potato Dextrose Agar medium}

Thirty nine grams (39g) of PDA powder was weighed and dissolved into 1ltr sterile distilled water in a two litre capacity conical flask. The suspension was heated using hot plate to dissolve the powder. The mouth of the flask was covered with cotton wool and wrapped with aluminum foil. It was sterilized using autoclave at $121^{\circ} \mathrm{C}$ for $15 \mathrm{~min}$ and the medium allowed to cool down to $50^{\circ} \mathrm{C}$. Streptomycin of $2.5 \mathrm{mg}$ was added to the medium and was slightly shaken, $40 \mathrm{ml}$ of the molten agar was dispensed into several sterile plates and let to solidify and it was allowed at room temperature overnight for sterility checking.

\section{Inoculation of the Soil Samples}

One gram $(1 \mathrm{~g})$ of each soil sample was weighed and poured in $10 \mathrm{ml}$ of sterile distilled water. Serial dilution was carried out on the first test tube by withdrawing $1 \mathrm{ml}$ and transferred to the second test tube containing $9 \mathrm{ml}$ of distilled water. From the second test tube, $0.5 \mathrm{ml}$ was inoculated in duplicate plates of PDA. A sterile glass rod was used to spread the suspensions in the entire surface of the PDA plates. Masking tape was used to seal the lid of the petri dish. All the inoculated plates were incubated in the laboratory for 5 days. The number of fungal growth showing blackish coloration was counted and sub-cultured separately onto fresh PDA plates to obtain pure fungal growth. 


\section{Identification of Aspergillus niger}

The fungal isolate was characterized based on macroscopic and microscopic appearance in terms of pigmentation, color of aerial and shape. A small portion of the mycelial growth was carefully picked with the aid of a pair of sterile dissecting needles and placed on a drop of lactophenol cotton blue on a slide covered with a cover slip. Examine the slide under the microscope with $\mathrm{x} 10$ and then with $\mathrm{x} 40$ objective lens to detect the spores and some special structures of the fungus.

\section{Pretreatment and Hydrolysis of Rice and Millet Husks Samples}

\section{Biological Pretreatment}

This was carried out as described by Bollock and Reczey (2000). Mandel's culture medium was prepared by adding $\left(\mathrm{gL}^{-1}\right)$ : urea $0.3,\left(\mathrm{NH}_{4}\right)_{2} \mathrm{SO} 41.4, \mathrm{KH}_{2} \mathrm{PO}_{4} 2, \mathrm{CaCl}_{2} 0.3, \mathrm{MgSO}_{4} 7 \mathrm{H}_{2} \mathrm{O} 0.3$, bacto peptone 0.75 , and yeast extract 0.25 . Trace elements were also added, using a $1 \%(\mathrm{v} / \mathrm{v})$ solution of salts (mll-1): $\mathrm{FeSO}_{4} 7 \mathrm{H}_{2} \mathrm{O} 0.5, \mathrm{MnSO}_{4} 0.16, \mathrm{ZnSO}_{4} 0.14, \mathrm{CoCl}_{2}$ 2. The $\mathrm{pH}$ adjusted to 5.5-6.0 before sterilization. Each sample $(30 \mathrm{~g})$ was put in a conical flask containing $300 \mathrm{ml}$ of Mandel's medium. The conical flask was plugged with cotton wool and sterilized at $15 \mathrm{lbs}$ per sq. inch for 20minutes. Each flask was inoculated with 5 discs of the fungi. These flasks were incubated at room temperature for 5days on an orbital shaker. After 5 days, the mycelium was separated by filtration through a whatman filter paper No.1. The filtrate was then used for further studies.

\section{Enzymatic Hydrolysis of Rice and Millet Husks Samples}

This was carried out as described by Okusanmi, (2008) and Gupta et al. (2009). A conical flask was labeled as A and B, thirty grams $(30 \mathrm{~g})$ of each pretreated sample was added into the flask with $300 \mathrm{ml}$ of distilled water. The flask was plugged with cotton wool and wrapped with aluminum foil. This was sterilized at $121^{\mathrm{O}} \mathrm{C}$ for 30 minutes. The flasks were inoculated with $1.5 \mathrm{ml}$ suspension of the isolated Aspergillus niger and incubated at $37^{\circ} \mathrm{C}$ for 5 days on an orbital shaker and the sample was filtered through Whatman filter paper size no. 1. The filtrate obtained was used for determination of reducing sugar content and fermentation.

\section{Determination of Reducing Sugar Contents}

The reducing sugar was estimated by using Dinitrosalicyclic acid calorimeter (DNS) method as described by Chandel et al. (2007). Glucose standard was prepared by dissolving $0.1 \mathrm{~g}$ of glucose into $100 \mathrm{~cm}^{3}$ of distilled water, $10 \mathrm{~cm}^{3}$ portion of the first standard pipette and transferred into another $100 \mathrm{~cm}^{3}$ volumetric flask and made to the mark using distilled water. To each test tube, $3 \mathrm{~cm}^{3}$ of DNS reagent was added. The content of each tube was placed in a boiling water bath for $10 \mathrm{~min}$ to develop red brown color. Then, $1 \mathrm{~cm}^{3}$ of $40 \%$ potassium sodium tartrate solution was added to stabilize the color while hot. It was allowed to cool at room temperature. The absorbance was measured at 508nm with a UV-visible spectrophotometer.

\section{C.R.S = $\underline{\text { Absorbance of each sample }} \quad \mathrm{x}$ Concentration of standard Absorbance of glucose standard}


Where; The concentration of standard $=5.5 \mathrm{mlmol} / \mathrm{L} \mathrm{C.R.S}=$ concentration of Reducing Sugar The results obtained in this study are mean \pm S.D of triplicate measurements.

\section{Determination of Viscosity of the Bio-ethanol Produced}

The viscometer was applied to charge the bio-ethanol produce in a manner designed by the manufacturer of the instrument. Standard sample was run first, followed by the sample to be tested. Test sample was placed into the capillary tube of the viscometer and level of the test sample adjusted with the help of pressure pump to the designated mark position on the capillary arm of the instrument at $5 \mathrm{~mm}$ ahead of the first timing mark with the sample flowing freely. Time was measured in second to within 0.25 the time needed for the meniscus to pass from the first to the next timing mark (in triplicate) and took average measurements as the flow time as described by Abdullahi, (2012). The Viscosity was calculated using the formula below:

Viscosity $=\mathrm{CT}$

Where; $\mathrm{C}=$ Calibration constant of the viscosity $\mathrm{T}=$ Flow time (sec)

\section{RESULTS}

TABLE 1: The Proximate and Elemental Composition of Rice and Millet Husks

\begin{tabular}{lcc}
\hline Parameters & Sample A: Rice Husks & Sample B: Millet Husk \\
\hline Moisture(\%) & $8.17 \pm 0.29$ & $26.67 \pm 0.58$ \\
Ash $(\%)$ & $20.17 \pm 0.58$ & $19.67 \pm 0.58$ \\
Volatile Solid(\%) & $71.67 \pm 0.76$ & $54.67 \pm 0.58$ \\
Total Solid(g) & $0.16 \pm 0.01$ & $0.51 \pm 0.01$ \\
Nitrogen $(\%)$ & $0.83 \pm 0.02$ & $0.52 \pm 0.02$ \\
Carbon $(\%)$ & $41.57 \pm 0.44$ & $31.71 \pm 0.33$ \\
C:N $(\%)$ & $50.09 \pm 0.96$ & $60.65 \pm 2.73$ \\
Phosphorus $(\mathrm{mg} / \mathrm{kg})$ & $0.18 \pm 0.001$ & $1.90 \pm 0.01$ \\
Potassium $(\mathrm{mg} / \mathrm{kg})$ & $1483 \pm 28.87$ & $566.7 \pm 57.74$
\end{tabular}

Values are in mean \pm S.D of triplicate measurements 


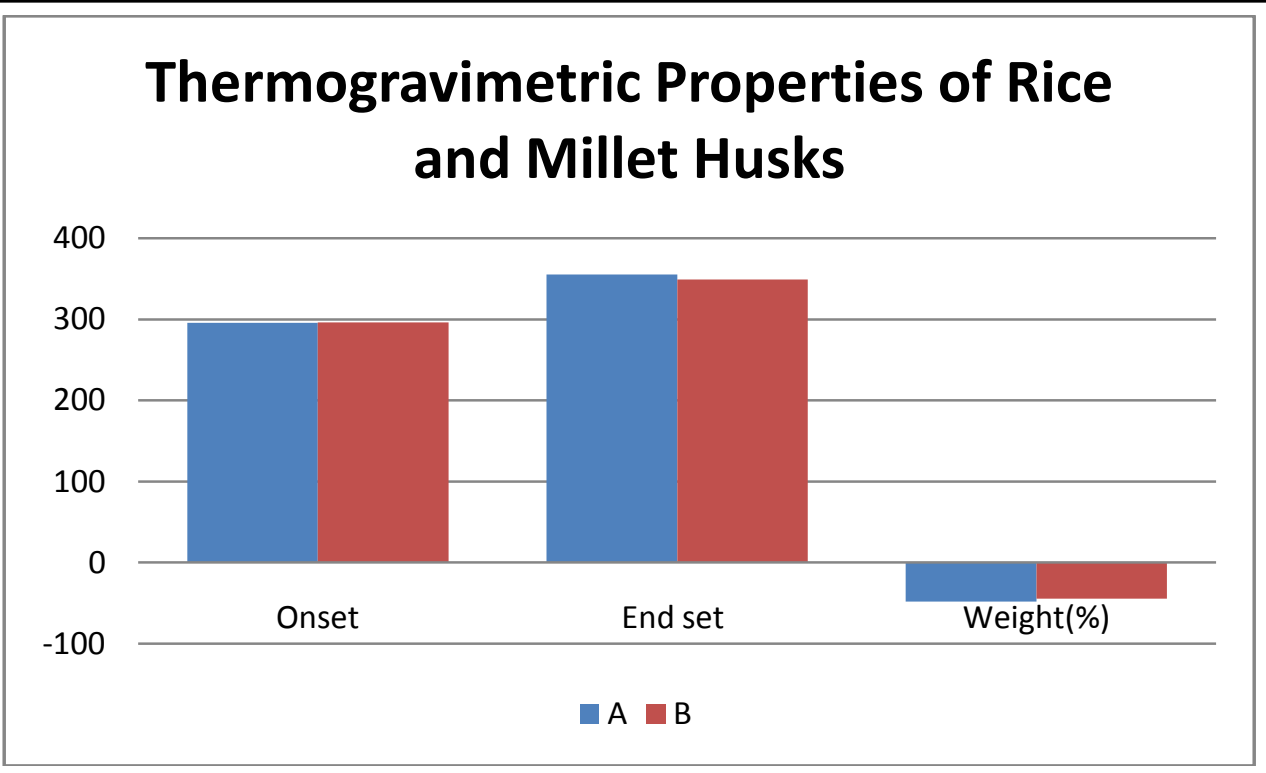

Figure 1: Thermogravimetric Properties of Rice and Millet Husks

TABLE 2: The macroscopy and microscopy Characteristics of Fungal Isolate

\begin{tabular}{llll}
\hline Sample & Macroscopy & Microscopy & Identified Organism \\
\hline FGS1 & Black mycelium & $\begin{array}{l}\text { Conidiophores baring } \\
\text { conidiospores. }\end{array}$ & Aspergillus niger \\
\hline
\end{tabular}

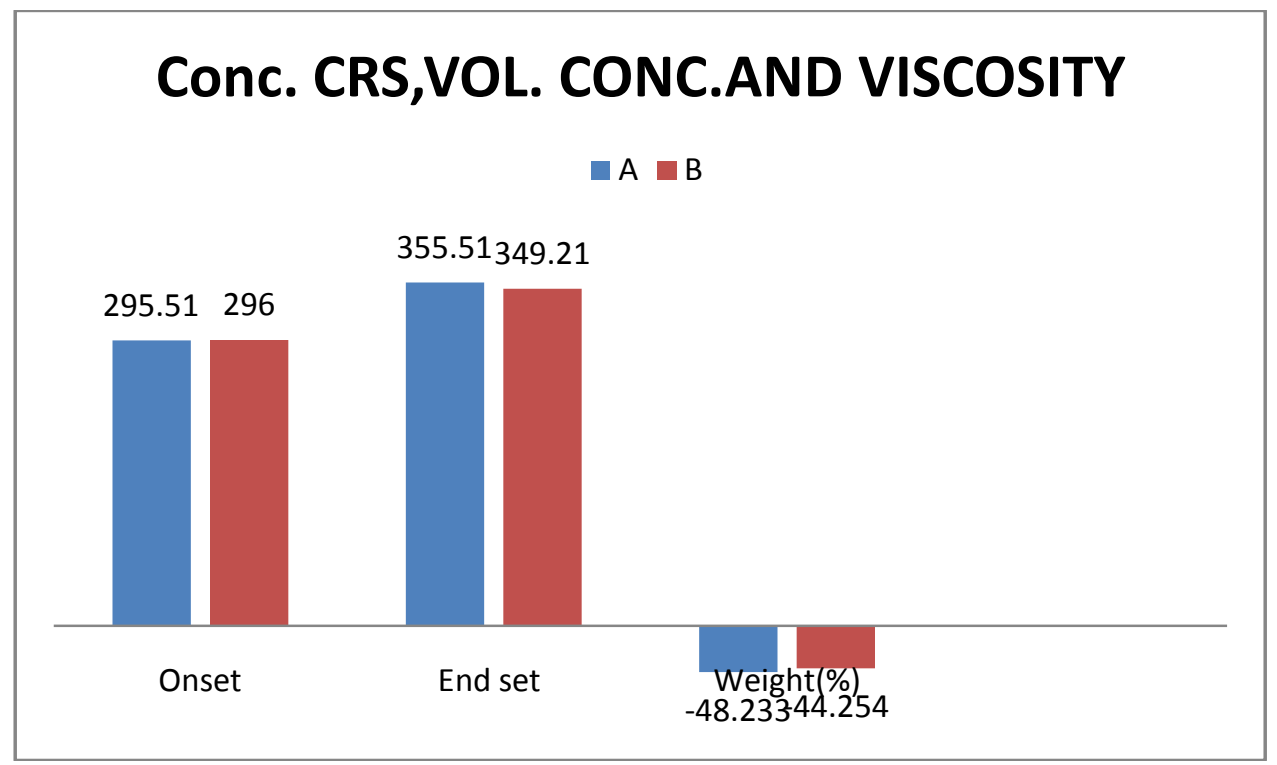

Figure 2

All analysis were done in triplicates; Mean \pm standard deviation (SD)

KEY: A=Rice husk, $B=$ Millet husk $\mathrm{CRS}=\mathrm{CON}$ 


\section{DISCUSION}

\section{Proximate and Elemental Composition of Rice and Millet Husks Samples}

The proximate and elemental composition of the biomass samples namely rice husks as sample A and millet husks as sample B is represented in Table1. Sample B had the highest moisture content of $26.67 \pm 0.58 \%$ when compared to sample A with $8.17 \pm 0.29 \%$. Whereas, the ash content was higher in sample A with $20.17 \pm 0.58 \%$ while sample B had $19.67 \pm 0.58 \%$. Sample A has higher with volatile solid $71.67 \pm 0.76 \%$, high nitrogen content with $0.83 \pm 0.02 \%$ and high carbon content with $41.57 \pm 0.44 \%$ in comparison to sample B which had low volatile solid of $54.67 \pm 0.58 \%$, low nitrogen content with $0.52 \pm 0.02 \%$ as well as low carbon content with $31.71 \pm 0.33$.

From the research conducted by Abba et al. (2014) where millet husk used revealed a moisture content of $10.0 \pm 0.03 \%$, Ash content with $33.83 \pm 0.67 \%$, volatile solids with $56.17 \pm 0.88 \mathrm{~g}$, carbon content of $32.58 \pm 1.10 \%$ and C:N $42.31 \%$. It also disagreed with the research reported by Morey et al. (2009) on biomass feed streams at ethanol plants which indicated a moisture content of $10.12 \pm 1.38 \%$, ash content with $3.41 \pm 0.27 \%$, volatile solid $82.50 \pm 1.32 \%$, carbon content $50.24 \pm 0.31 \%$ and nitrogen content with $4.79 \pm 0.34 \%$.

The results obtained in this study differ with the results obtained by Abba et al, (2014) and Morey et al. (2009). The difference could be as a result of seasonal variation during sample collection and the type of biomass substrate used. Statistical analysis revealed that there is a significant difference $(p<0.05)$ among the samples analysed.

\section{Thermogravimetric Properties of the Rice and Millet Husks Samples}

The results in Figure 1 indicate the thermogravimetric properties of the biomass samples. Sample A had the least onset temperature $295.51^{\circ} \mathrm{C}$, end set temperature $355.51^{\circ} \mathrm{C}$ and the greatest weight loss with the largest degradation rate occurred in stage II with $-48.23 \%$. In the study, stages I, II, and III occurred in the temperature ranges of $26^{\circ} \mathrm{C}-250^{\circ} \mathrm{C}, 125^{\circ} \mathrm{C}-530^{\circ} \mathrm{C}$, and $375^{\circ} \mathrm{C}-775^{\circ} \mathrm{C}$, respectively. For the low-moisture (4\% to $10 \%$ w.b.) the greatest weight loss with the largest degradation rate occurred in stage I. This results differed with that reported by Biswas and Staff (2001), Wang et al.(2007) and Morey et al (2009) this may be due to the differences in composition between the samples and due to the differences in the experimental conditions (such as heating rate and air purging rate) used for the TGA analysis.

\section{Isolation and Identification of the Specie (Aspergillus niger)}

The result in Table 2 showed the fungus isolated for the purpose of pretreatment and hydrolysis of biomass samples. The culture showed black mycelium on the surface of PDA plates and was identified as Aspergillus niger. This is in agreement with the work of Oyeleke and Jibrin (2009) where Aspergillus niger showed a black mycelium on the agar plate, with septate hyphae, long and smooth conidiospores, and long unbranched sporangiopores with a large round head. 


\section{Bioethanol Production from Rice and Millet Husks}

The results in Figure 2 indicates the concentration of reducing sugar $\left(\mathrm{mol} / \mathrm{dm}^{3}\right)$, the quantity/volume $(\mathrm{g} / \mathrm{ml})$ of the bioethanol produced after hydrolysis of the biomass using Aspergillus niger and fermentation with Saccharomyces cerevisiae. It revealed that sample A had the highest reducing sugar $2.59 \pm 1.24 \mathrm{~mol} / \mathrm{dm}^{3}$ when compared with sample B that had $1.63 \pm 0.68 \mathrm{~mol} / \mathrm{dm}^{3}$. Rice husk indicated low yield after 7 days fermentation period but showed high yield in the volume of ethanol produced $68.67 \pm 17.69 \mathrm{~g} / \mathrm{l}$ for sample A and $79.80 \pm 0.93 \mathrm{~g} / \mathrm{l}$ for sample B. This study is contrary to the analysis conducted by Itelima et al (2013) using banana, plantain and pineapple peels to produce bioethanol. Also, a study carried out by Abba et al, (2014) using millet husk revealed that millet husk hydrolysed with $3 \%$ (V/V) $\mathrm{H}_{2} \mathrm{SO}_{4}$ released the highest percentage of reducing sugar $(21.40 \%)$. A study by Rabah et al (2011) on the hydrolysis of agrowastes using different acid concentration and temperature treatments revealed high yield of reducing sugars. High yields were obtained from millet husk hydrolysates at all the temperature regimes used $\left(30^{\circ} \mathrm{C}, 40^{\circ} \mathrm{C}\right.$ and $\left.50^{\circ} \mathrm{C}\right)$, most importantly at $4 \%$ acid concentration. However, at $5 \%$ acid concentration, high yields were obtained from millet husk hydrolysates at $30^{\mathrm{O}} \mathrm{C}$ for 25 and 30 minutes and at $5 \%$ acid concentration at $50^{\circ} \mathrm{C}$ for 25 and 30 minutes.

The volume of rice and millet husks sample from this study also disagree with the research conducted by Oyeleke and Jibrin (2009) using guinea corn husk and millet husk, which revealed ethanol yield for guinea corn husk $26.83 \mathrm{~g} / \mathrm{l}$ and millet husk $18.31 \mathrm{~g} / \mathrm{l}$. It also does not agree with the research conducted by Lekneth et al, (1994) using sweet sorghum as substrate (27.7g/l).

\section{CONCLUSION AND RECOMMENDATIONS}

The potentials and viability of the rice-millet husks were identified based on the results obtained in the research work. The elemental composition of the rice husks were within $0.18 \pm 0.001 \%$ to $41.57 \pm 0.44 \%$ for rice husk and that of millet husk were $0.52 \pm 0.02 \%$ to $60.65 \pm 2.73 \%$. The Concentrations of reducing sugar was $1.63 \pm 0.68 \mathrm{~mol} / \mathrm{dm}^{3}$ for rice husk and $2.59 \pm 1.24 \mathrm{~mol} / \mathrm{dm}^{3}$ for millet husk. The concentration of rice husk was found to be $0.54 \pm 0.01 \mathrm{mg} / \mathrm{l}$ and for the millet husk $0.03 \pm 0.01 \mathrm{mg} / \mathrm{l}$. The highest onset, end set and weight loss were within the ranges of $296^{\mathrm{O}} \mathrm{c}-$ $355.5^{\circ} \mathrm{c}$ and the weight loss of -48.23 for rice husk. There are needs to further studies on utilization of agricultural wastes such as the rice and millet husk for bioethanol production and The Use of biological pretreatment should be encouraged because of it advantages and it requires low energy and mild environmental conditions. 


\section{REFERENCE}

Abba, A., Faruq, U.Z., Birnin Yauri, U.A., Yerima, M.B. and Umar, K.J. (2014).Study on Production of Biogas and Bioethanol from Millet husk. Annual Research and Review in Biology.4(5): 817-827.

Abdullahi, A.S. (2012) Biodiesel Production and Characterization from Pumpkin Phd Thesis Submitted to the Department of Pure and Applied Chemistry, UDU, Sokoto.

Allen, S.E., Grinshaw, H.M., Parlinson, J.A. and Qurmbly, C. (1974). Chemical Analysis of Ecological Materials. Blackwell scientific publication, London.32: 299.

Bagudo, B.U., Garba, B., Dangoggo, S.M. and Hassan, L.G. (2008).Comparative Study of Biogas Production from Locally Soured Substrate Materials. Nigerian Journal of Basic and Applied Science, 16 (2):262-266.

Bakare, (1985). Methods of Biochemical Analysis of Plant Tissues. (unpublished document), Agronomy Department, University of Ibadan.137-148.

Biswas, S., and Staff, C. (2001). Analysis of Headspace Compounds of Distillers Grains using SPME in Conjunction with GC-MS and TGA. Journal of Cereal Science 33 (2): 223-229.

Chandel, A.K., da Silva, S.S. and Singh, O.V. (2013). Detoxification of Lignocellulose Hydrolysates: Biochemical and Metabolic Engineering toward White Biotechnology. Bioenergy Research, 6(1):388-401

Cheesbrough, M. (2003).Medical Laboratory Manual.Tropical Health Technology. Low priced edition. Doddington, Cambridgeshire, England.20-35.

Demirbas, A. (2005). Bioethanol from Cellulosic Materials: A Renewable Motor Fuel From Biomass. Energy Source.27: 327-337.

Garba, B., Zuru, A.A. and Sambo, A.S. (1996).Effect of Concentration on Biogas Production from Cattledung.Nigerian Journal of Renewable Energy 4:38-43.

Gupta, R., Sharma, K.K. and Kuhad, R.C. (2009). Simultaneous Saccharification and Fermentation of Prosopis jutiflora, a Woody Substrate, for the Production of Cellulosic Ethanol by Saccharamyces cerevisiae and Pichia stipitis- NCIM 3498. Bioresource Technology; 100: 1214-1220.

Hongguange, W. (2006). Biomass Energy Development Welcoming Bright Prospects.www.en.ce .cn/Insight/200703/02/t20070302 10560407.shetml. Retrieved 2015-12-04.

Itelima, J.F., Onwuliri, E.O., Onyimba, I. and Oforji, S. (2013). Bioethanol Production from Banana, Plantain and Pineapple Peels by Simultaneous Saccharification and fermentation Process. International Journal of Environmental Science and Development. 4 (2): 213216 
Kang, Q., Appels, L., Baeyens, J., Dewil, R. and Tan, T. (2014).Energy-efficient Production of Cassava-based Bio-Ethanol. Advances in Bioscience and Biotechnology,5(12): 925-939.

Lekneth, V., Christaopouls, P. and Marris, B. (1994).Bioethanol Technology Review.Journal ofBiotechnology, 16: $983-988$.

Leuenberger, H. and Wohlgemuth, N. (2006). Biofuels and Energy Security in Africa.http:www.gfse.at/fileadmin/dam/gfse\%206/PLENARY IV/GFSE2006.pdf] Retrieved 2014 November, 18.

Morey, R.V., Hatfield, D.L., Sears, R., Haak, D., Tiffany, D.G. and Kaliyan, N. (2009).Fuel Properties of Biomass Feed Streams at Ethanol Plants. Applied Engineering in Agriculture 25 (1): 57-64.

Okusanmi, T.A. (2008). Optimization of Ethanol Production from Agricultural Residues using Microorganisms Isolated from the Rumen of Ruminants. MSc. Thesis Fed Uni. of Tech. Minna. Niger state, Nigeria.

Oyeleke, S. B. and Jibrin, N. M. (2009).Production of Bioethanol from Guinea Corn Husk and Millet Husk.African Journal of Microbiology Research.3(4): 147 - 152.

Oyeleke, S.B. and Manga, S.B. (2008).Essentials of Laboratory Practicals in Microbiology. $1^{\text {st }}$ ed, Tobest Publishers S.W. 225 Hospital road Minna, Niger State. 28, 33, 36, 51 and 58.

Pillay, D.G., and Da. Silver, E. J. (2009).Sustainable Development and Bio economic Prosperity in Africa: Bio-fuels and the South African Gateway. African Journal of Biotechnology, 8(11): 2397-2408.

Rabah, A.B., Oyeleke, S.B., Manga, S.B. and Hassan, L.G. (2011). Utilization of Millet and Guinea corn Husks for Bioethanol Production. African Journal of Microbiology Resource.5(31): 5721-5724

Rabah, A. B., Oyeleke, S. B., Manga, S. B. and Hassan, L. G. (2011).Dilute Acid Pretreatment of Millet and Guineacorn Husks for Bioethanol Production. International Research Journal of Microbiology. 2(11): 460-465.

Wang, L., Kumar, A., Weller, C. L. Jones, D. D. and Hanna. M. A. (2007).Co-production of Chemical and Energy Products from Distillers Grains using Supercritical Fluid Extraction and Thermochemical Conversion Technologies. ASABE Paper No. 076064. St. Joseph, Mich.: ASABE. 